\title{
Výzkum proudění mostním objektem s volnou hladinou a zatopeným vtokem
}

\section{PETRA PODEŠVOVÁ, ALEŠ HAVLÍK}

Klíčová slova: most - volná hladina - průtokový součinitel - fyzikální modelování - matematické modelování

\section{SOUHRN}

Př́spěvek prezentuje výsledky hydraulického výzkumu proudění mostním objektem s volnou hladinou a zatopeným vtokem na fyzikálním modelu. Srovnává dosavadní poznatky s naměřenými daty a diskutuje rozdíly. Př́spěvek obsahuje analýzu tvorby zúžené hloubky za vtokem do mostního otvoru. Rovněž zpracovává závislost průtokového součinitele na řadě faktorů, jež je prezentována pomocí grafư a rovnic. Závěr práce dává doporučení pro volbu průtokového součinitele při výpočtech v softwaru Hec-Ras.

\section{ÚVOD}

Hydraulický výzkum proudění mostním objektem pro prípad zatopeného vtoku a volného výtoku byl řešen na Fakultě stavební ČVUT v Praze v letech 2017 až 2019 v rámci projektu studentské grantové soutěže SGS17/171/OHK1/3T/11, jehož hlavní řešitelkou byla Ing. Petra Podešvová. Tento článek byl napsán za podpory tohoto projektu.

Základem řešení byl fyzikální výzkum, při kterém byl využit stávající skleněný žlab v hydraulické laboratoři fakulty. Vzhledem k rekonstrukci haly v posledním roce řešení byl výzkum doplněn i o simulace na 3D matematickém modelu.

\section{SOUHRN DOSAVADNÍCH POZNATKU゚}

\section{Výtok pod stavidlem}

Proudění mostním otvorem se zatopeným vtokem a volným výtokem je blízké výtoku pod stavidlem. Charakteristický podélný profil hladiny pro prípad výtoku pod stavidlem, kdy proudění není ovlivněno dolní vodou, je znázorněn na obr. 1 .

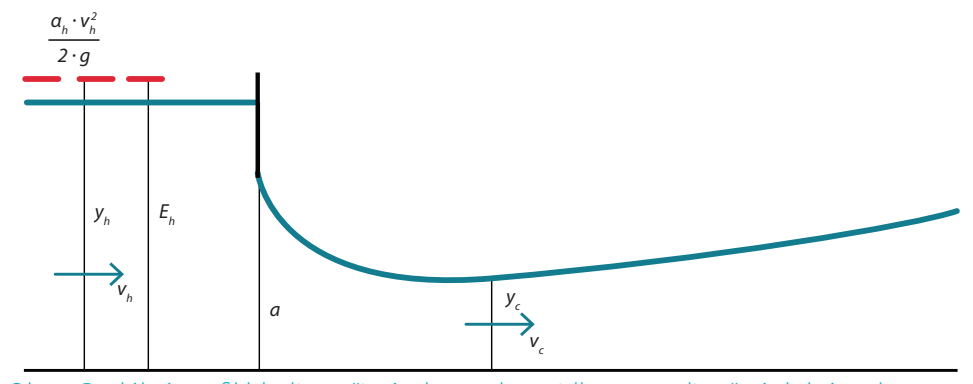

Obr. 1. Podélný profil hladiny při výtoku pod stavidlem neovlivněný dolní vodou Fig. 1. Water level profile at sluice gate flow not affected by the downstream flow
Při nezatopení dolní vodou se vytvárí zúžená hloubka $y_{c} \approx 0,6 a$. Bernoulliho rovnice pro daný prípad je:

$$
E_{h}=y_{h}+\frac{a_{h} v_{h}^{2}}{2 g}=y_{c}+\frac{a_{c} v_{c}^{2}}{2 g}+\frac{\xi_{z} v_{c}^{2}}{2 g}=y_{c}+\frac{v_{c}^{2}}{\varphi^{2} 2 g}
$$

kde $E_{h}[m]$ je energetická výška před vtokem do objektu,

$y_{h}[\mathrm{~m}] \quad$ hloubka pred vtokem do objektu,

$v_{h}\left[\mathrm{~m}^{-1} \mathrm{~s}^{-1} \quad\right.$ průrezová rychlost proudění před vtokem do objektu,

$y_{c}[\mathrm{~m}] \quad$ zúžená hloubka za výtokovým profilem,

$v_{c}\left[\mathrm{~m} \cdot \mathrm{s}^{-1}\right] \quad$ prưřezová rychlost v profilu zúžené hloubky,

$a[-] \quad$ Coriolisovo číslo,

$\xi_{z}[-] \quad$ součinitel místní ztráty zúžením proudu,

$\varphi[-] \quad$ rychlostní součinitel.

Při uvažování:

$$
y_{c}=\varepsilon_{V} a
$$

kde $a[m]$ je výška otvoru,

$$
\varepsilon_{v}[-] \quad \text { součinitel zúžení, }
$$

po dosazení rovnice spojitosti do rovnice (1) a po zavedení výtokového součinitele dostaneme pro průtok:

$$
Q=\mu_{v} a b \sqrt{2 g\left(E_{h}-y_{c}\right)}
$$

$$
\begin{array}{ccc}
\text { kde } & b[\mathrm{~m}] & \text { je šírka otvoru, } \\
& \mu_{v}[-] & \text { výtokový součinitel. }
\end{array}
$$

Běžně publikované závislosti uvedených součinitelů na poměru $y_{h} / a$ jsou vykresleny na obr. 2.

\section{Výpočet proudění mostním objektem se zatopeným vtokem a volným výtokem}

Obdobné schéma a výpočtový postup jako pro případ výtoku pod stavidlem (rovnice (3)) bylo pro případ výpočtu proudění mostním objektem se zatopeným vtokem a volným výtokem publikováno Bradleym ve zprávě FHWA [1], 


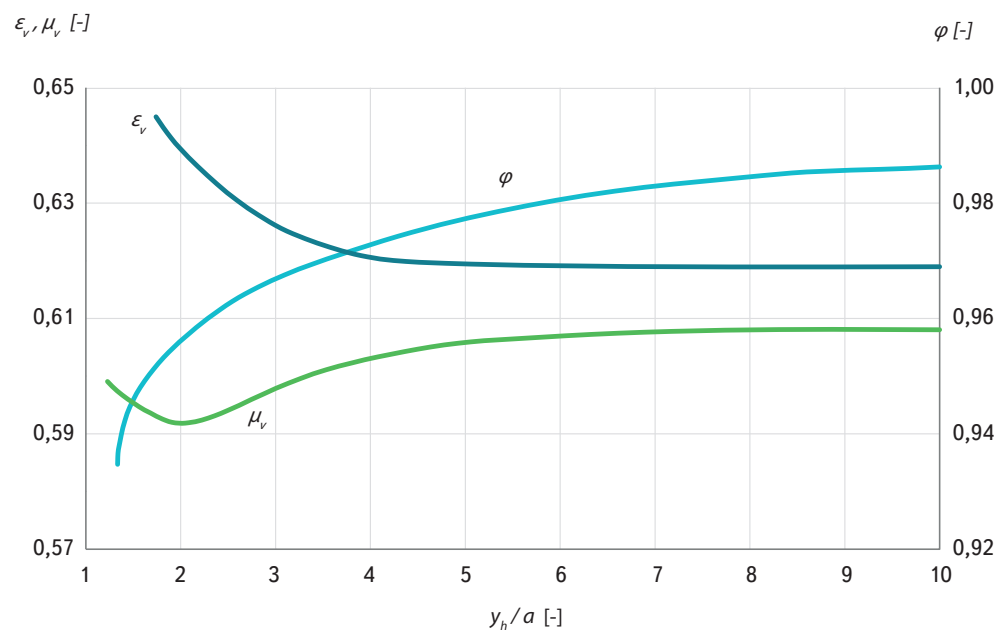

Obr. 2. Závislost součinitelů $\varepsilon_{v^{\prime}} \mu_{v}$ a $\varphi$ na poměru $y_{h} / a$

Fig. 2. Dependence of coefficients $\varepsilon_{v} \mu_{v}$ and $\varphi$ on the ratio $y_{h} / a$

zúžená hloubka y je však uvažována jako polovina výšky mostního otvoru $H_{m} / 2$. Podélný profil pro tento prípad je vykreslen na obr. 3. Rovnice pro výpočet průtoku má tvar:

$$
Q=C_{D} H_{m} B_{m} \sqrt{2 g\left(E_{h}-\frac{H m}{2}\right)}
$$

kde $Q\left[\mathrm{~m}^{3} \cdot \mathrm{s}^{-1}\right]$ je průtok,

$C_{D}[-] \quad$ průtokový součinitel,

$H_{m}[\mathrm{~m}] \quad$ světlá výška mostního otvoru,

$B_{m}^{m}[m] \quad$ světlá šířka mostního otvoru (bez piliriru).

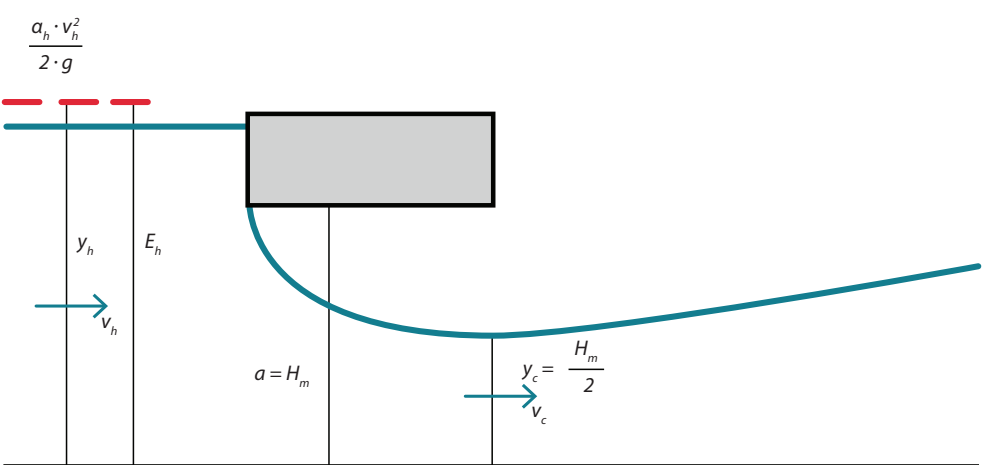

Obr. 3. Podélný profil hladiny při proudění mostním objektem se zatopeným vtokem a volným výtokem při uvažování $y_{c}=H_{\mathrm{m}} / 2$

Fig. 3. Water level profile at bridge with free and submerged inlet when $y_{c}=H_{m} / 2$

V této publikaci je uveden graf závislosti průtokového součinitele $C_{D}$ na parametru $y_{h} / H_{m^{\prime}}$ respektive na $y_{h} / y_{d^{\prime}}$ který je přiložen na obr. 4 . Zde $y_{d}$ značí hloubku dolní vody. Průběh závislosti ukazuje, že proudění mostním objektem se zatopeným vtokem a volným výtokem pro hodnoty $y_{h} / H_{m}<1,05$ nemusí být stabilní, hodnota průtokového součinitele se $v$ této oblasti pohybuje kolem hodnoty 0,3 , s nárůstem velikosti poměrů se postupně zvyšuje až k hodnotě 0,5.

Rovnice (4) pro výpočet proudění mostním objektem se zatopeným vtokem a volným výtokem byla dále publikována v další publikaci FHWA [2], graf pro stanovení $C_{D}$ již však obsahuje jen závislost na $y_{h} / H_{m} s$ úpravou v oblasti hodnot $y_{h} / H_{m}<1,08$, graf je uveden na obr. 5 .

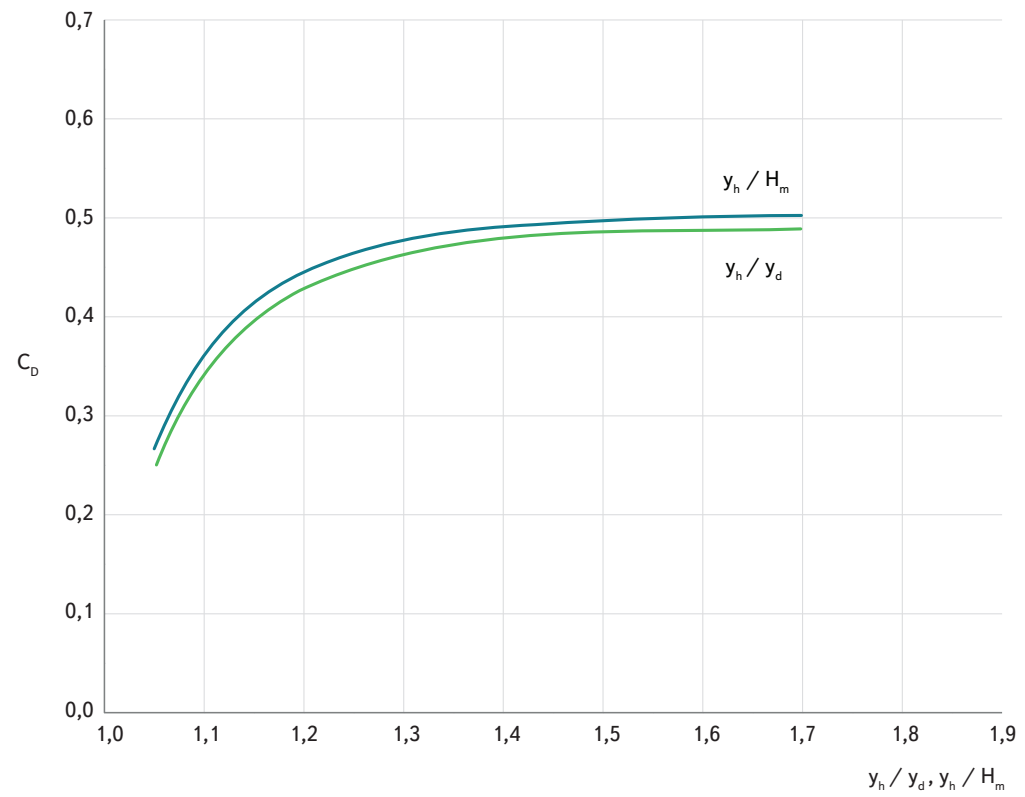

Obr. 4. Závislost průtokového součinitele $C_{D}$ na poměru $y_{h} / H_{m}$ a $y_{h} / y_{d}$ podle Bradleyho [1] Fig. 4. Dependence of discharge coefficient $C_{D}$ on ratio $y_{h} / H_{m}$ and $y_{h} / y_{d}$ according to Bradley [1]

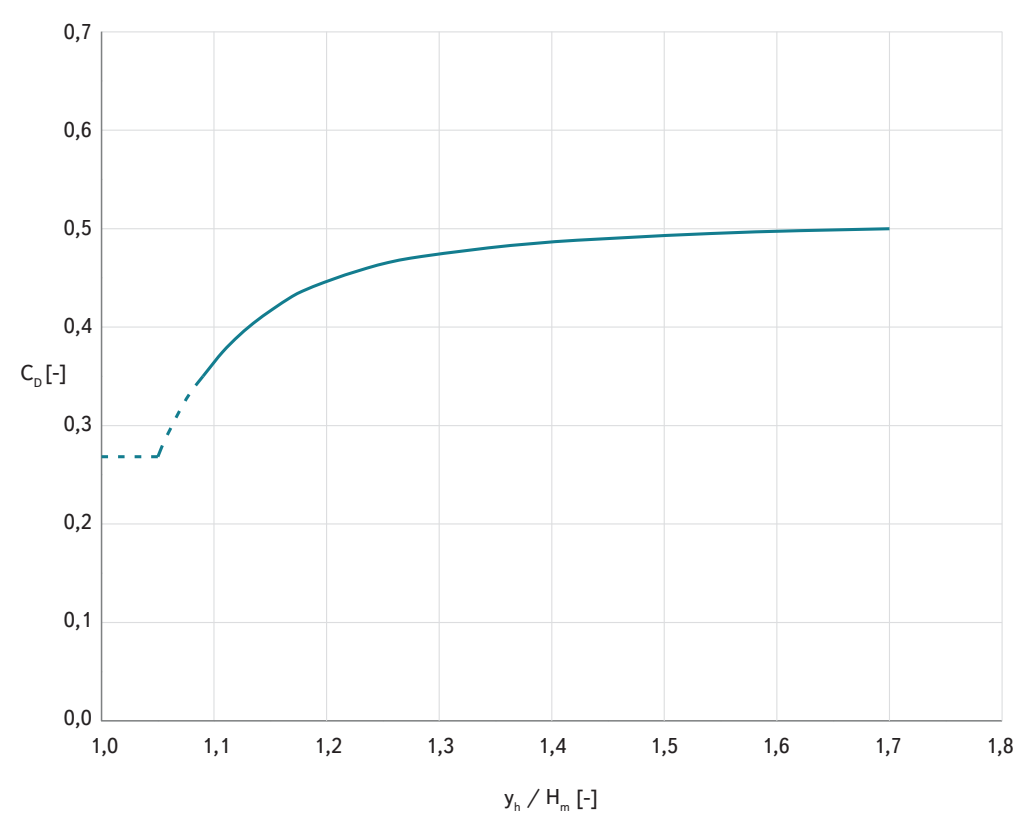

Obr. 5. Závislost průtokového součinitele $C_{D}$ na poměru $y_{h} / H_{m}$ podle Zevenbergena [2] Fig. 5. Dependence of discharge coefficient $C_{D}$ on ratio $y_{h} / H_{m}$ according to Zevenbergen [2]

Rovnici (4) uvádí bez grafu ke stanovení $C_{D}$ ve své monografii Hamill [3], postup uvedený v publikaci [2] pak používá beze změny u nás hojně využívaný software Hec-Ras [4].

\section{Výpočet tlakového proudění mostním objektem}

Problematikou proudění mostním otvorem při tlakovém proudění se v rámci svého výzkumu velmi podrobně zabýval Picek [5]. Typický podélný profil hladiny pro tento scénář je zobrazen na obr. 6 . 


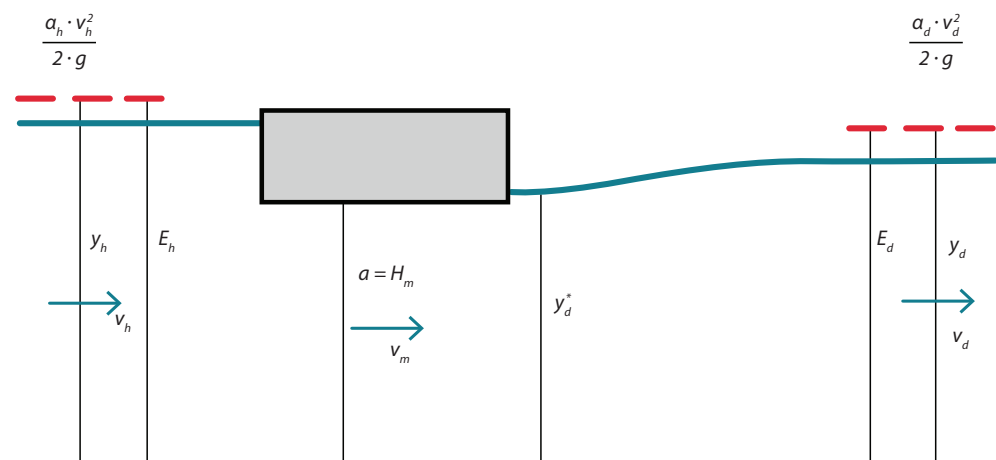

Obr. 6. Schéma podélného profilu pro případ tlakového proudění mostním objektem Fig. 6. Water level profile at bridge with pressurized flow

Při zanedbání ztrát třením je možné při uvažování ztrát zúžením a následujícím rozšířením proudu napsat tuto Bernoulliho rovnici:

$$
E_{h}=y_{h}+\frac{a_{h} \cdot v_{h}^{2}}{2 \cdot g}=y_{d}+\frac{a_{d} \cdot v_{d}^{2}}{2 \cdot g}+z_{z}+z_{R}
$$

kde $y_{d}[m]$ je hloubka za výtokem z mostního objektu,

$v_{d}\left[m \cdot s^{-1}\right] \quad$ průřezová rychlost proudění v profilu za výtokem z mostního objektu,

$Z_{z}[\mathrm{~m}] \quad$ ztráta zúžením na vtoku do mostního otvoru,

$Z_{R}[\mathrm{~m}] \quad$ ztráta rozšiřením na výtoku z mostního otvoru.

Ztráty zúžením je možné vyjádřit v závislosti na průřezové rychlosti ve vtokovém profilu mostu, ke stanovení ztrát rozšířením je možné použít více postupů (obdoba Bordovy ztráty pro náhlé rozšíření průměru potrubí jako funkci rozdílu rychlostních výšek na začátku a konci rozšiření proudu nebo analogie ztráty na výtoku do velké nádrže). Podrobně se touto problematikou ve své práci zabývala Jurečková [6]. Rovnici, která využívá poslední príistup, publikoval například Hamill [3]:

$$
Q=C_{D O} S_{m} \sqrt{2 g\left(E_{h}-y_{d}\right)}
$$

kde $C_{\mathrm{DO}}[-]$ je průtokový součinitel,

$\mathrm{S}_{\mathrm{m}}=B_{\mathrm{m}} H_{\mathrm{m}} \quad$ plocha vtokového otvoru.

Picek [5] však doporučuje pro druhý profil v Bernoulliho rovnici použít profil bezprostředně za výtokem z mostního otvoru, kde se vytváŕí hloubka $y_{d}{ }^{*}<y_{d^{\prime}}$ pro výpočet proudění tlakovým mostním objektem pak doporučuje užívat rovnici:

$$
Q=C_{D O} S_{m} \sqrt{2 g\left(E_{h}-y_{d}^{*}\right)}
$$

kde $\quad y_{d}^{*}[\mathrm{~m}]$ je hloubka těsně za výtokem z objektu (viz obr. 6).

Vyhodnocení součinitele $C_{D 0}$ z experimentů na fyzikálním modelu podle obou rovnic je patrné na obr.7.

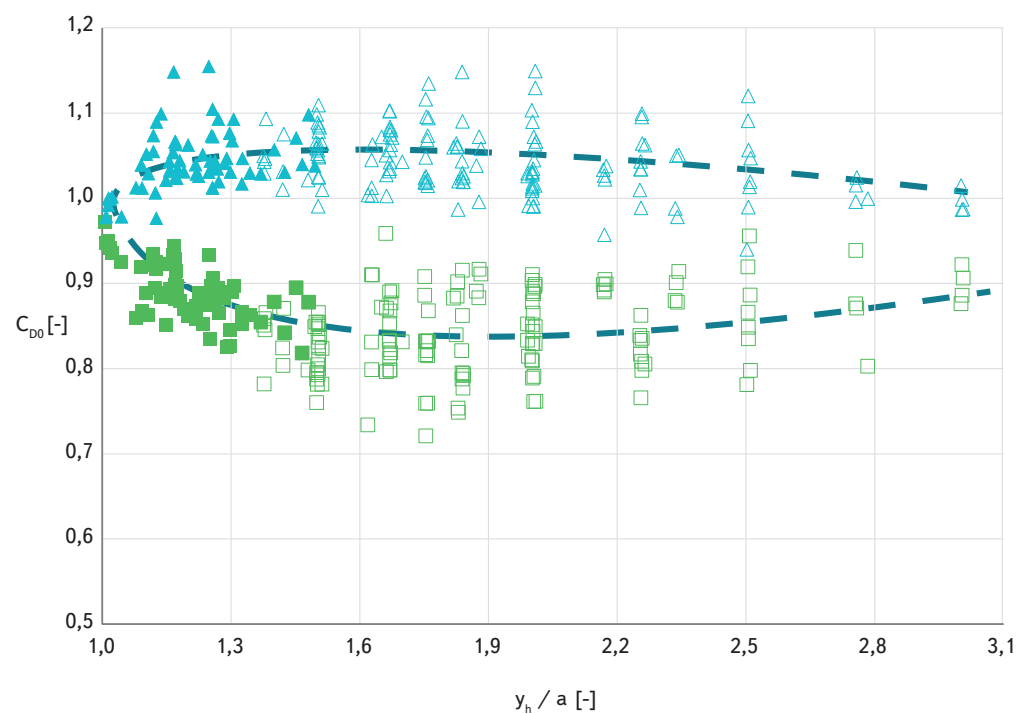

Rovnice (7) s yd* pro tlakové proudění $\quad$ Rovnice (7) s yd* pro přelévanou mostovku

Rovnice (6) s yd pro tlakové proudění $\quad$ Rovnice (6) s yd pro přelévanou mostovku

Obr. 7. Hodnoty průtokového koeficientu $C_{D 0}$ pro tlakové proudění vyhodnocené na základě experimentu podle rovnice (6), resp. (7)

Fig. 7. Values of discharge coefficient $C_{D 0}$ for pressurized flow obtained during the experiment according to the equation (6), respectively (7)

\section{METODIKA VÝZKUMU}

\section{Modelová podobnost}

Hydraulický výzkum byl založen na fyzikálním modelování při proudění s volnou hladinou. V tomto případě jsou dominantními silami síly gravitační a pro vyhodnocení se využívá Froudův zákon modelové podobnosti. Ten vyjadřuje skutečnost, že ve vzájemně príslušných profilech na modelu a ve skutečnosti budou stejná Froudova čísla. Bezrozměrné Froudovo číslo Fr je definováno rovnicí:

$$
F r=\frac{V}{\sqrt{g y}}
$$

kde $\quad v\left[m \cdot s^{-1}\right]$ je průřezová rychlost proudění, $y$ [m] střední hloubka v profilu.

Pro bezrozměrné veličiny, na které se při vyhodnocení výzkumu řešitelé zaměřili, ovšem platí, že hodnota z modelu má stejnou hodnotu i pro skutečnost.

\section{Popis modelu}

Výzkum byl prováděn ve Vodohospodářské hale Fakulty stavební ČVUT v Praze. Měření probíhalo $v$ hydraulickém žlabu s nulovým podélným sklonem. Jeho rozměry byly následující: šîrka 252 mm, délka 7300 mm, výška stěn v první části 1000 mm, v druhé části 500 mm. Začátek žlabu byl osazen voštinovým usměrňovačem pro rovnoměrné rozdělení proudu a na jeho konci byl umístěn žaluziový uzávěr sloužící k regulaci hloubky dolní vody. 
Do žlabu byly postupně vkládány modely mostního objektu. Délka mostního objektu byla 100 mm a šiřka mostního otvoru byla 130 mm, přičemž byly použity tři verze modelu lišící se světlou výškou mostního otvoru v rozměrech 80 mm, 100 mm a 120 mm. Jejich príčné řezy byly převzaty z diplomové práce Adély Dostálové [7] a jsou přiloženy na obr. 8.
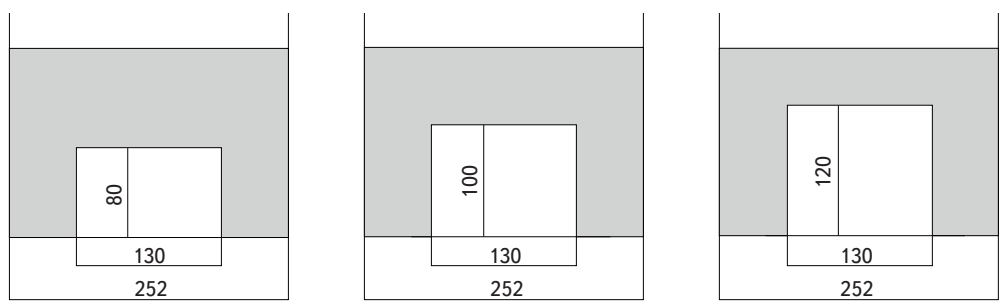

Obr. 8. Příčné řezy modelů mostních objektů včetně jejich rozměrů v [mm] [7] Fig. 8. Cross sections of bridge models including their dimensions in [mm] [7]

\section{Měření veličin}

$\checkmark$ rámci provedeného výzkumu byly měřeny pouze dvě veličiny, a to výška úrovní hladiny a průtok modelem. Úrovně hladin byly měřeny pomocí posuvného hrotového měřítka a hodnoty byly odečítány s presností 0,1 mm. Pro měření průtoků byla použita dvě zařízení - indukční průtokoměr Magnetoflow Primo a měrný Thomsonův přeliv.

Během výzkumu bylo změřeno celkem 57 průběhů hladin. Pro každou variantu mostního objektu byly změřeny průběhy hladin pro čtyři hodnoty průtoku a pro každý z nich byly uvažovány čtyři varianty míry ovlivnění dolní vodou, celkem tedy 16 měření průběhu hladin. Na základě prvotního vyhodnocení bylo rozhodnuto o nutnosti doměření několika stavů zejména pro vyšší hodnoty průtoků na vtoku do mostního objektu.

Měření výšky hladiny bylo prováděno $v$ bodech rozmístěných rovnoměrně v podélném a příčném směru, v blízkosti mostního objektu byla sít měřených bodů zhuštěna (viz obr. 9 převzatý z diplomové práce [7]). Ve většině příčných profilů bylo měření prováděno $v$ pěti bodech, kdy jeden bod byl $v$ ose proudění, další dva v jedné a třech čtvrtinách šířky od kraje žlabu a poslední dva body byly umístěny u kraje žlabu. Měrené body jsou znázorněny na obr. 9 červeně, zelenou barvou je zde znázorněno umístění mostního objektu.

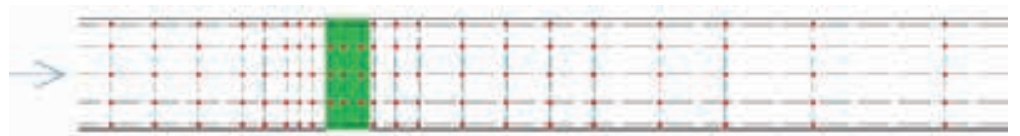

Obr. 9. Sít měřených bodů v hydraulickém žlabu

Fig. 9. Mesh of the measured points in the hydraulic flume

\section{VÝSLEDKY EXPERIMENTÁLNÍHO VÝZKUMU}

Prohlídka rozsáhlého souboru dat, který byl během experimentálních prací pořízen, ukázala, že pro studium scénáre se zatopeným vtokem a volným výtokem bylo nezbytné ponechat jen některé pokusy, kdy se vyskytovala volná hladina pod celou délkou reálné mostní konstrukce. V souboru dat, který byl dále podroben statistické analýze, bylo ponecháno 34 průběhů hladin.

Typický průběh hladiny při experimentech je vykreslen na obr. 10. Za vtokovým profilem docházelo k postupnému snižování hladiny na hodnotu $y_{c^{\prime}}$ $\checkmark$ naprosté většině prípadů se tato hloubka objevovala přibližně ve vzdálenosti 2/3 délky mostního objektu. Pak se hladina postupně zvyšovala až k hodnotě y

Pro dané schéma je možné sestavit Bernoulliho rovnici mezi profilem zúžené hloubky y a vzduté hloubky nad mostem y ve tvaru (1) nebo mezi profilem $s$ hloubkou dolní vody $y_{d}$ a vzduté hloubky nad mostem $y_{h}$ ve tvaru (5).

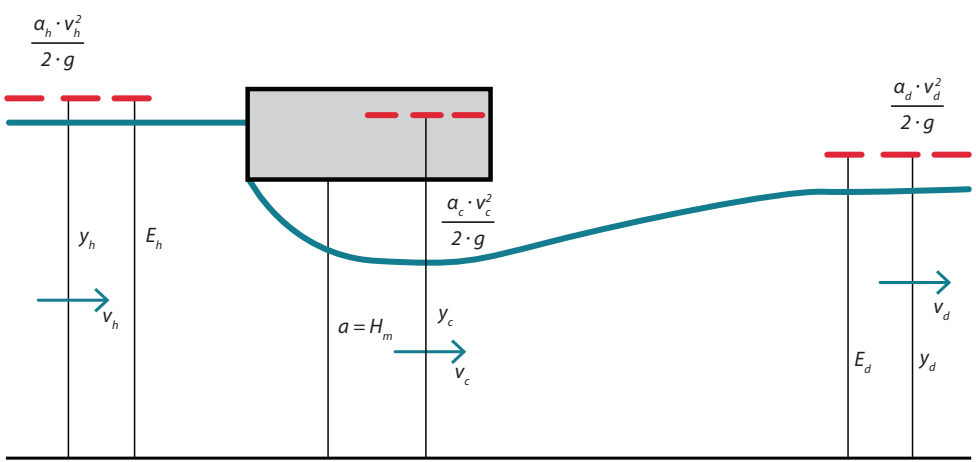

Obr. 10. Podélný profil hladiny vyskytující se při experimentálním měření Fig. 10. Water level profile observed at the experimental measurements

Možnosti stanovení ztrát jsou popsány u rovnice (5), k vyčíslení ztrát je potřeba znát velikost rychlosti $v_{c} v$ profilu zúžené hloubky $y_{c} \cdot v$ průběhu experimentů však rychlostní pole měěeno nebylo a řešitelé aktivní śiřku proudění v zúženém profilu $B$ pouze odhadovali na základě porovnání se simulacemi vybraných scénářu $s$ využitím 3D matematického modelu. V rámci navazujícího výzkumu se počítá $s$ tím, že se řešitelé zaměři právě na vyhodnocení rychlosti $v_{c^{\prime}}$ která bude nezbytná pro vyhodnocení ztrát zúžením i rozšírením proudu.

Proto řešitelé $v$ této fázi výzkumu zaměřili svou pozornost zejména na posouzení správnosti výpočtu vzduté úrovně hladiny nad mostem v prípadě zatopeného vtoku a volného výtoku podle prístupu Bradleyho. Zkušenosti s užíváním softwaru Hec-Ras, který tento postup používá, ukazují, že vypočítaná hloubka proudění nad mostním objektem y dává v případě proudění se zatopeným vtokem a volným výtokem často vyšší hodnotu, než pro větší průtok, kdy je proudění objektem již plně tlakové. Rovnice využívá diskutabilní hodnotu zúžené hloubky za vtokem jako $0,5 \cdot H_{m^{\prime}}$ zatímco při výtoku otvorem to bývá podle obr. 2 cca 0,6 $\cdot H_{\mathrm{m}}$. Vyhodnocení experimentů pak ukázalo, že vytvoření průběhu hladiny se zatopeným vtokem a volným výtokem bylo dosaženo často jen při zatopení zúžené hloubky $0,6 \cdot H_{m}$ dolní vodou. Tuto skutečnost dokládá graf na obr. 11.

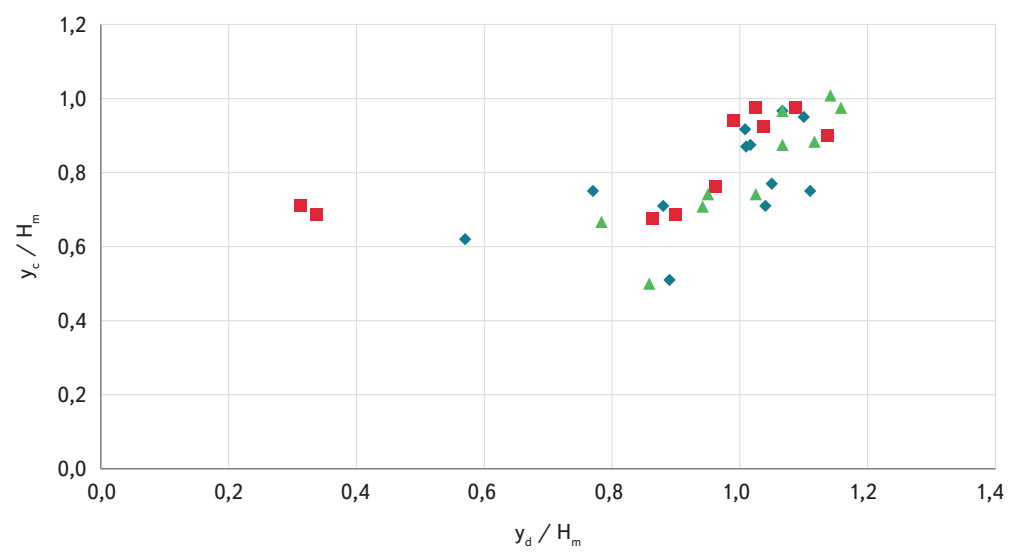

\section{$\mathrm{Bm} / \mathrm{Hm}=1,625 \quad \mathrm{Bm} / \mathrm{Hm}=1,3 \quad \mathrm{Bm} / \mathrm{Hm}=1,086$}

Obr. 11. Závislost poměru $y_{c} / H_{m}$ na $y_{d} / H_{m}$ pro provedené experimenty se zatopeným vtokem a volným výtokem

Fig. 11. Dependence of ratio $y_{c} / H_{m}$ on $y_{d} / H_{m}$ for experiments with free flow and submerged face of the deck 
Na obr. 12 jsou zobrazeny hodnoty průtokového součinitele $C_{D}$ stanovené z rovnice (4) pro známé hodnoty $Q, E_{h^{\prime}} H_{m}$ a $B_{m}$ stanovené vyhodnocením experimentů. Průběh bodů byl následně proložen křivkou, jejíž průběh je popsán rovnicí (9), fialovou čárou je pak vyznačen průběh Bradleyho závislosti. Pouhým okem je patrné, že naprostá většina hodnot součinitele $C_{D}$ je větší než podle Bradleyho.

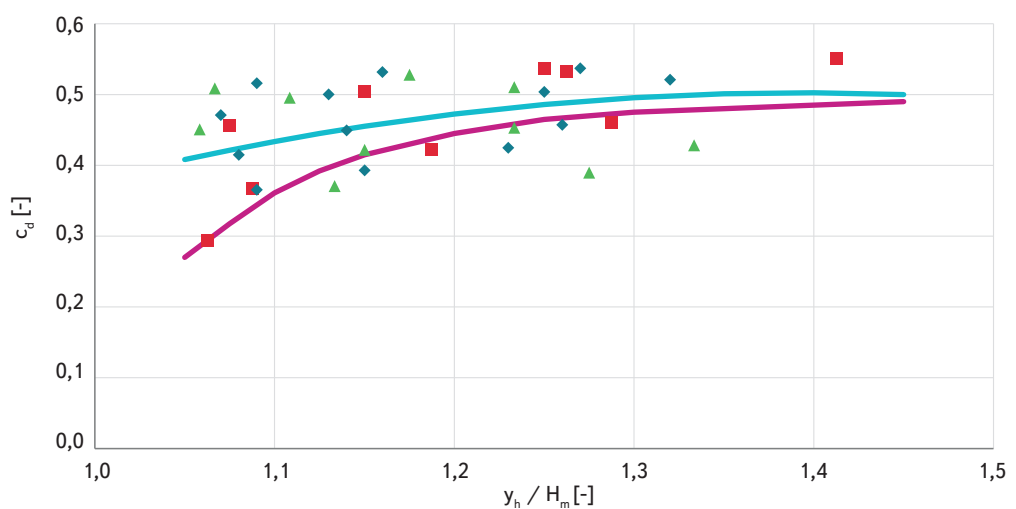

\section{$\mathrm{Bm} / \mathrm{Hm}=1,625 \quad \mathrm{Bm} / \mathrm{Hm}=1,3 \quad \mathrm{Bm} / \mathrm{Hm}=1,086 \quad \mathrm{Cd}=\mathrm{f}(\mathrm{yh} / \mathrm{H}) \quad$ Bradley}

Obr. 12. Závislost průtokového součinitele $C_{D}$ na poměru $y_{b} / H_{m}$

Fig. 12. Dependence of discharge coefficient $C_{D}$ on ratio $y_{h} / H_{m}$

$$
C_{D}=-0,7975\left(\frac{y_{h}}{H_{m}}\right)^{2}+2,2233\left(\frac{y_{h}}{H_{m}}\right)-1,047, \text { prì: } r^{2}=0,2098
$$

Jiný pohled na součinitel $C_{D}$ dává obr. 13, kde je zobrazena jeho závislost tentokrát na poměru $y_{d} / H_{m}$. Vzhledem $k$ tomu, že software Hec-Ras neumožňuje řešit podrobný průběh hladiny v profilu mostního objektu a v prípadě, že úroveň hladiny dolní vody je vyšší než spodní líc mostovky, program automaticky uvažuje tlakové proudění, byl průběh doplněn o proložení bodů s menšími hodnotami, než je $y_{\mathrm{d}} / H_{\mathrm{m}}<0,97$ lineární závislostí podle rovnice:

$$
C_{D}=-0,1016\left(\frac{y_{d}}{H_{m}}\right)+0,586, \text { při: } r^{2}=0,4920
$$

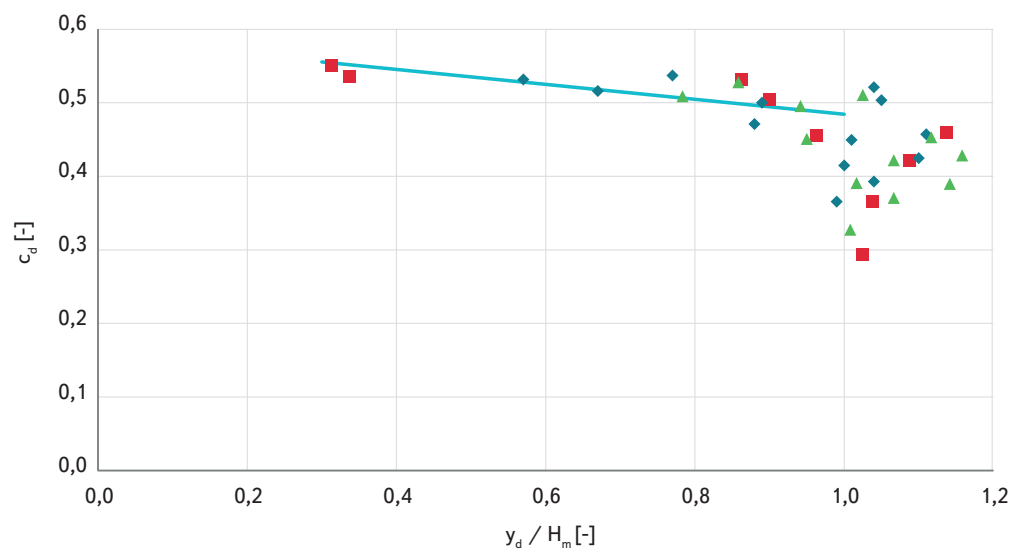

Obr. 13. Závislost průtokového součinitele $C_{D}$ na poměru $y_{d} / H_{m}$

Fig. 13. Dependence of discharge coefficient $C_{D}$ on ratio $y_{d} / H_{m}$

Na posledním obr. 14 je pak znázorněn průběh závislosti součinitele $C_{\mathrm{Do}^{\prime}}$ jehož hodnoty byly spočítány podle rovnice (6), na poměru $y_{d} / H_{m}$. Zde je nezbytné uvést, že uvedená rovnice po fyzikální stránce nepopisuje proudění mostním objektem se zatopeným vtokem a volným výtokem zcela správně.

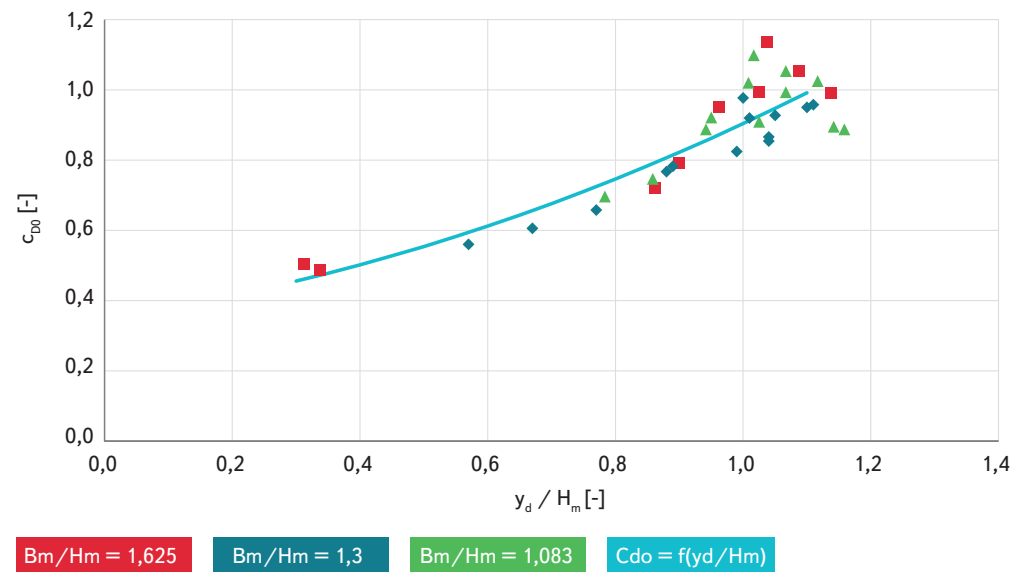

Obr. 14. Závislost součinitele $C_{D 0}$ stanoveného podle rovnice (6) na poměru $y_{d} / H_{m}$ Fig. 14. Dependence of coefficient $C_{D 0}$ obtained from equation (6) on ratio $y_{d} / H_{m}$

Průběh závislosti vykreslených bodů na obr. 14 byl proložen funkcí podle rovnice:

$$
C_{D 0}=0,2966\left(\frac{y_{d}}{H_{m}}\right)^{2}+0,2546\left(\frac{y_{d}}{H_{m}}\right)+0,3526, \text { pri: } r^{2}=0,7705
$$

Jedním z dalších cílů řešitelů bude nalézt výpočetní postupy, které zajistí spojité řešení výpočtu vzduté hloubky nad mostem při přechodu ze stavu se zatopeným vtokem a volným výtokem na plně tlakové proudění, což software Hec-Ras neposkytuje. Porovnání grafu na obr. 14 s výstupy výzkumu Picka podle obr. 7 na možné propojení ukazují.

\section{ZÁVĚR}

Vyhodnocení experimentů na fyzikálním modelu při proudění mostním objektem se zatopeným vtokem a volným výtokem ukázaly na to, že výpočet vzduté hloubky nad mostem y s využitím rovnice (4) a stanovením průtokového součinitele $C_{D}$ podle závislosti podle grafu na obr. 5 může dávat př́liš velké hodnoty.

Na základě provedené analýzy zejména pak grafu na obr. 13 se v případě užití softwaru Hec-Ras doporučuje nepouživat postup, kdy program sám odečte hodnotu $C_{\mathrm{D}} z$ uvedené závislosti, ale doporučuje se pro hodnoty $y_{d} / H_{m} \vee$ rozsahu od 0,7 do 0,95 použít hodnotu $C_{D}=0,5$, pro hodnotu poměru menší než 0,7 přibližně $C_{D}=0,525$. 


\section{Literatura}

[1] BRADLEY, J.N. Hydraulics of Bridge Waterways. Federal Highway Administration, hds 1, March 1978.

[2] ZEVENBERGEN, L.W., ARNESON, L.A., HUNT, J.H., and MILLER, A.C. Hydraulics Design of Safe Bridges. Federal Highway Administration, hds 7, April 2012

[3] HAMILL, L. Bridge Hydraulics. London: Spon Press, 1999, 367 s. ISBN 0-419-20570-5.

[4] BRUNNER, G.W. HEC-RAS 5.0, River Analysis System Hydraulic Reference Manual. US Army Corps of Engineers [online]. February 2016. [vid. 7. 10. 2019]. Dostupné z: http://www.hec.usace.army.mil/ software/hec-ras/documentation

[5] PICEK, T. Hydraulic calculation of bridges at high water stages. Journal of Hydraulic Research, 2007, Vol. 45, No. 3, p. 400-406.

[6] JUREČKOVÁ, P. Modelový výzkum prouděni na výtoku z propustku. Diplomová práce ČVUT v Praze Fakulta stavebni, Katedra hydrauliky a hydrologie. Praha, 2017.

[7] DOSTÁLOVÁ, A. Analýza proudění mostním objektem se zatopeným vtokem. Diplomová práce ČVUT v Praze, Fakulta stavební, Katedra hydrauliky a hydrologie. Praha, 2019.

\section{Autoři}

Ing. Petra Podešvová

冈petra.podesvova@fsv.cvut.cz

doc. Ing. Aleš Havlík, CSc.

凶ales.havlik@fsv.cvut.cz

Fakulta stavební, České vysoké učení technické v Praze

Přispěvek prošel lektorským řízením.

DOI: 10.46555/VTEI.2020.03.002
RESEARCH OF FLOW THROUGH BRIDGE STRUCTURE WITH FREE WATER SURFACE AND SUBMERGED INLET

\section{PODESVOVA, P.; HAVLIK, A.}

Faculty of Civil Engineering, CTU in Prague

Keywords: bridge - free water surface - discharge coefficient physical modeling - mathematical modeling

The paper presents the results of hydraulic research of flow through bridge structure with free water surface and submerged inlet on a physical model. It compares current knowledge with measured data and discusses the differences. The paper contains an analysis of creation of the contracted depth at the bridge inlet. It processes the discharge coefficient dependence on several factors as well. These are presented with graphs and equations. The conclusion gives recommendation for choosing the discharge coefficient while computing in Hec-Ras software. 